\title{
The TCF7L2 rs7903146 (C/T) polymorphism is associated with risk to type 2 diabetes mellitus in Southern-Brazil
}

\author{
O polimorfismo rs7903146 (C/T) no gene TCF7L2 está associado com \\ risco para o diabetes melito tipo 2 em uma população do sul do Brasil
}

Taís S. Assmann ${ }^{1,2}$, Guilherme C. K. Duarte', Jakeline Rheinheimer ${ }^{1,2}$, Lavínia A. Cruz', Luís H. Canani ${ }^{1,2}$, Daisy Crispim ${ }^{1,2}$

${ }^{1}$ Endocrine Division, Hospital de Clínicas de Porto Alegre (HCPA), Porto Alegre, RS, Brazil 2 Post-graduate Program in Medical Sciences: Endocrinology, Universidade Federal do Rio Grande do Sul (UFRGS), Porto Alegre, RS, Brazil
Correspondence to: Daisy Crispim

Divisão de Endocrinologia,

Hospital de Clínicas de Porto Alegre Rua Ramiro Barcelos, 2350,

prédio $12,4^{\circ}$ andar

90035-003 - Porto Alegre, RS, Brazil

daisy_crispim@hotmail.com

Received on June/3/2014 Accepted on Sept/14/2014

DOI: $10.1590 / 0004-2730000003510$

\begin{abstract}
Objective: The aim of this study was to investigate the association between the rs7903146 (C/T) polymorphism in the TCF7L2 gene and type 2 diabetes mellitus, in a Southern-Brazilian population. Materials and methods: The TCF7L2 rs7903146 polymorphism was genotyped in 953 type 2 diabetic patients and 535 non-diabetic subjects. All subjects were white. The polymorphism was genotyped by Real-Time PCR using TaqMan MGB probes (Life Technologies). Odds ratios (OR) and $95 \%$ confidence intervals $(\mathrm{Cl})$ were calculated for additive, recessive and dominant inheritance models. Results: Genotype and allele frequencies of the rs7903146 polymorphism differed significantly between type 2 diabetic patients and non-diabetic subjects $(P=0.001$ and $P=0.0001$, respectively). The frequency of the minor allele was $38 \%$ in type 2 diabetes group and $31 \%$ in non-diabetic subjects, and this allele was significantly associated with type 2 diabetes risk (OR $=1.42$, $95 \% \mathrm{Cl} 1.15-1.76$ for the dominant model of inheritance). Moreover, the T/T genotype was associated with a higher risk for type 2 diabetes $(\mathrm{OR}=1.83,95 \% \mathrm{Cl} 1.3-2.5)$ than the presence of only one copy of the T allele $(\mathrm{OR}=1.31,95 \% \mathrm{Cl} 1.1-1.6)$. Both results were adjusted for age and gender. Conclusions: Our results confirm the association between the TCF7L2 rs7903146 polymorphism and increase risk for type 2 diabetes in Southern-Brazil. Arq Bras Endocrinol Metab. 2014;58(9):918-25
\end{abstract}

Keywords

Single nucleotide polymorphism; type 2 diabetes mellitus; transcription factor 7 -like 2 (TCF7L2)

\section{RESUMO}

Objetivo: O objetivo deste estudo foi investigar a associação entre o polimorfismo rs7903146 (C/T) no gene TCF7L2 e o diabetes melito tipo 2 em uma população do sul do Brasil. Materiais e métodos: O polimorfismo rs7903146 (C/T) no gene TCF7L2 foi genotipado em 953 pacientes com diabetes melito tipo 2 e em 535 indivíduos não diabéticos. Todos os indivíduos estudados eram brancos. O polimorfismo foi genotipado por meio da técnica de PCR em tempo real, utilizando sondas TaqMan MGB (Life Technologies). A razão de chances e o intervalo de confiança de $95 \%$ foram calculados para os modelos de herança: aditivo, recessivo e dominante. Resultados: As frequências genotípicas e alélicas do polimorfismo rs7903146 diferiram significativamente entre os pacientes com diabetes melito tipo 2 e indivíduos não diabéticos ( $\mathrm{P}=0,001$ e $\mathrm{P}=0,0001$, respectivamente). A frequência do menor alelo foi $38 \%$ no grupo dos pacientes com diabetes melito tipo 2 e $31 \%$ no grupo dos indivíduos não diabéticos, sendo esse alelo significativamente associado com risco para o diabetes melito tipo 2 ( $R C=1,42 ;$ IC 95\% 1,15-1,76 para o modelo de herança dominante). Do mesmo modo, o genótipo T/T foi associado com risco maior para o diabetes melito tipo 2 (RC $=1,83$; IC 95\% 1,3-2,5) do que a presença de apenas uma cópia do aleloT $(\mathrm{RC}=1,31 ; \mathrm{IC} 95 \% 1,1$ $-1,6)$. Ambos os resultados foram ajustados para idade e gênero. Conclusões: Nossos resultados confirmam a associação entre o polimorfismo rs7903146 no gene TCF7L2 e o risco para o diabetes melito tipo 2 em uma população do sul do Brasil. Arq Bras Endocrinol Metab. 2014;58(9):918-25

Descritores

Diabetes melito tipo 2; polimorfismos de DNA; fator de transcrição 7-like 2 (TCF7L2) 


\section{INTRODUCTION}

$\mathrm{T}$ ype 2 diabetes mellitus (T2DM) is a heterogeneous group of disorders usually characterized by the incapability of pancreatic beta cells to increase insulin secretion to compensate the insulin resistance in peripheral tissues (1). T2DM is a multifactorial disease, and the susceptibility to it is determined by several genetic and environmental factors, in an orchestrated manner (2). The most likely explanation for the remarkable increase in T2DM prevalence observed over the past decades is changing patterns of diet, as well as lack of physical activity practice. However, it is supposed that these lifestyle changes may lead to T2DM, but only in the presence of genetic risk factors for this condition (2). For that reason, great effort has been made in an endeavor to identify genes associated with T2DM, and many loci associated with this disease have been uncovered by genetic association studies and genome-wide association scan (GWAS).

In this scenario, in early 2006, a large scale GWAS study reported that some single nucleotide polymorphisms (SNPs) in the TCF7L2 gene were strongly associated with risk to T2DM in an Iceland case-control sample (3). The results presented in this study were substantial, with each additional copy of the risk allele being associated with an odds ratio (OR) of 1.5 , and with an outstanding $\mathrm{P}$ value of $7.8 \times 10^{-15}$ (3). Afterwards, this association has been replicated by numerous groups among different ethnicities, also with very low $P$ values [reviewed in (4)]. Up to now, all of these studies firmly establish TCF7L2 gene as the strongest genetic risk factor for T2DM (4-8). Amongst the TCF7L2 variants, two intronic SNPs (rs12255372 and rs7903146) are the most closely associated with T2DM, and although both have showed a significant linkage disequilibrium $(\mathrm{LD})$, the rs7903146 $(\mathrm{C} / \mathrm{T})$ variant seems to have the strongest effect in Caucasian populations $(4,9)$.

The TCF7L2 gene encodes a transcription factor involved in the Wnt signaling pathway, which plays an important role in pancreatic islet development and adipogenesis (10). TCF7L2 forms heterodimers with $\beta$-catenin, inducing the expression of various genes, including the insulinotropic hormone glucagon-like peptide 1 (GLP-I) gene, the insulin gene, and other genes that encode proteins involved in processing and exocytose of insulin granules $(9,11-13)$. As GLP-1 and insulin play a key role in blood glucose homeostasis, it was hypothesized that TCF7L2 variants may modify T2DM susceptibility by indirectly reducing GLP-1 secretion from enteroendocrine cells (14). On the other hand, as the Wnt pathway seems to be important for pancreas development during embryonic growth, it is also possible that the beta-cell mass, pancreatic beta-cell development and/or beta-cell function are also affected by this pathway (15). However, the exact molecular mechanism underlying the association of TCF7L2 polymorphisms with T2DM remains to be enlightened $(15,16)$.

Because the frequency of the TCF7L2 rs7903146 T allele has been shown variable among different populations (17-23), which could influence the effect of this SNP on T2DM susceptibility, in the present study, we investigated the potential association of the TCF7L2 rs7903146 (C/T) polymorphism with T2DM, in white Brazilian subjects. In addition, the genetic association of this SNP with T2DM has not yet been studied in Southern Brazil.

\section{MATERIALS AND METHODS}

\section{Subjects}

A total of 1,488 unrelated subjects were enrolled in this case-control study. The diabetic sample comprised 953 T2DM patients participating in a multicentre study that began recruiting patients in Southern Brazil in 2002. That project was originally designed to study risk factors associated with T2DM and its chronic complications. It included four Centers in teaching hospitals located in the Brazilian state of Rio Grande do Sul. A detailed description of that study can be found elsewhere (24). T2DM was diagnosed according to the American Diabetes Association criteria (25). The main characteristics of the T2DM patients were as follows: mean age was $59.3 \pm$ 10.7 years, mean T2DM duration was $12.5 \pm 9.5$ years, mean age at $\mathrm{T} 2 \mathrm{DM}$ diagnosis was $46.3 \pm 11.4$ years, mean glycated hemoglobin $(\mathrm{HbAlc})$ was $7.7 \pm 1.7 \%$, and mean body mass index (BMI) was $28.7 \pm 5.1 \mathrm{~kg} / \mathrm{m}^{2}$. Males comprised $51.0 \%$ of the sample, $71.0 \%$ of all patients had arterial hypertension $(\mathrm{AH})$, and $34.2 \%$ had obesity.

The non-diabetic group comprised 535 healthy volunteers attending the blood donation facility at Hospital de Clínicas de Porto Alegre (Porto Alegre, Brazil; mean age $=44.0 \pm 7.8$ years; males $=51.0 \%)$. None of these subjects reported presence of diabetes or a family history of this disease. All subjects had Caucasian ancestry (mostly of Portuguese, Spanish, Italian and German descent), and were self defined as white. 
A standard questionnaire was used to collect information regarding age, age at T2DM diagnosis, and drug treatment. All T2DM patients underwent physical examination and laboratory evaluations, as previously reported (26). BMI was calculated as weight $(\mathrm{kg}) /$ height square (meters). Presence of obesity was defined as BMI $\geq 30 \mathrm{~kg} / \mathrm{m}^{2}$. Office blood pressure (BP) was measured in sitting position, on the left arm, after a 5 -min rest by a trained researcher, with a mercury sphygmomanometer. The mean of two measurements taken 1 min apart was used to calculate systolic and diastolic BP. Arterial hypertension $(\mathrm{AH})$ was defined as BP levels higher than $140 / 90 \mathrm{mmHg}$ at the initial visit and at two follow-up visits within 1 month of the initial visit, or if the presence of $\mathrm{AH}$ was previously registered on medical records.

Serum and plasma from T2DM patients were taken after a 12 hours of fasting for laboratory analyses (26). Plasma glucose levels were determined using the glucose oxidase method. HbAlc measurements were performed by different methods and results were traceable to the Diabetes Control and Complications Trial (DCCT) method by off-line calibration or through conversion formulae (27). Total plasma cholesterol, HDL cholesterol and triglycerides were assayed using enzymatic methods.

The information obtained from the study did not influence patients' diagnosis or treatment. The study protocol was approved by the Ethic Committee in Research from Hospital de Clínicas de Porto Alegre and all patients and non-diabetic subjects provided written informed consent.

\section{Genotyping}

DNA was extracted from peripheral blood leucocytes by a standardized salting-out procedure (28). TCF7L2 rs7903146 (C/T) SNP was genotyped using primers and probes contained in the 40x Human Custom TaqMan Genotyping Assay (Life Technologies, Foster City, CA, USA), as previously reported (29). Sequences of primers and probes were: TCF7L25'CCTCAAAACCTAGCACAGCTGTTAT3' (forward primer), TCF7L2-5' TGAAAACTAAGGGTGCCTCATACG3' (reverse primer), TCF7L2-FAM-5' AAGCACTTTTTAGATATTATAT3'; TCF7L2-VIC-5' CTAAGCACTTTTTAGATACTATAT3'. Reactions were conducted in 96-well plates, in a total of $5 \mu \mathrm{L}$ volume using 2 ng of genomic DNA, TaqMan Genotyping Master Mix lx (Life Technologies) and Custom TaqMan Genotyping Assay lx. Plates were then loaded in a real- time PCR thermal cycler (7500 Fast Real PCR System; Life Technologies) and heated for $10 \mathrm{~min}$ at $95^{\circ} \mathrm{C}$, followed by 50 cycles of $95^{\circ} \mathrm{C}$ for $15 \mathrm{~s}$ and $62^{\circ} \mathrm{C}$ for $1 \mathrm{~min}$. The genotyping success rate was better than $95 \%$, with a calculated error based on PCR duplicates of less than $1 \%$.

\section{Statistical analyses}

Allelic frequencies were determined by gene counting and departures from the Hardy-Weinberg equilibrium (HWE) were verified using $\chi^{2}$ tests. Clinical and laboratory characteristics were compared between groups by using One-way ANOVA, unpaired Student's $t$ test or $\chi^{2}$, as appropriate. Variables with normal distribution are presented as mean \pm SD or percentage. Variables with skewed distribution were log-transformed before analyses and are shown as median (range).

The magnitude of associations of the TCF7L2 rs7903146 SNP with T2DM were estimated using odds ratio (OR) with $95 \%$ confidence interval $(\mathrm{CI})$. Multivariate logistic regression analyses were performed to assess the independent association of this SNP with T2DM, adjusting for age and gender. Moreover, in T2DM patients, logistic regression analysis was also performed using obesity as a dependent variable and age and gender as independent variables. Associations between the rs7903146 SNP and T2DM characteristics (continuous variables) were tested using general linear model (GLM) analyses, adjusting for covariates.

Results for which the $\mathrm{P}$ value was under 0.05 were considered statistically significant. Bonferroni correction was used to account for multiple comparisons. These statistical analyses were performed using SPSS version 18.0 (SPSS, Chicago, IL). Power calculations were done using the software PEPI, version 4.0, and showed that this study has a power of approximately $80 \%$ at a significance level of 0.05 to detect an OR of 1.4 or higher, for the presence of the minor allele.

\section{RESULTS}

Genotype and allele frequencies of rs7903146 (C/T) SNP in T2DM patients and non-diabetic subjects are shown in table 1 . All genotypes were in agreement with those predicted by the HWE in non-diabetic subjects $(\mathrm{P}=0.208)$. Both genotype and allele frequencies of the rs7903146 SNP were differently distributed between T2DM and non-diabetic subjects after Bonferroni corrections $(\mathrm{P}=0.001$ and $\mathrm{P}=0.0001$, respectively). Genotype frequencies of the rs7903146 SNP remained 
significantly associated with T2DM after adjustment for age and gender (Table 1). In agreement with this data, the $\mathrm{T}$ allele was significantly associated with risk for T2DM under a dominant model of inheritance, adjusting for age and gender $(\mathrm{OR}=1.42,95 \% \mathrm{CI} 1.15$ $-1.76 ; \mathrm{P}=0.001)$. Moreover, homozygosis for the $\mathrm{T}$ allele was associated with a higher risk for T2DM $(\mathrm{OR}$ $=1.83,95 \% \mathrm{CI} 1.3-2.5, \mathrm{P}=0.001)$ than the presence of only one copy of this allele $(\mathrm{OR}=1.31,95 \%$ CI 1.1 $-1.6 ; \mathrm{P}=0.017$ ), adjusting for age and gender.

Table 2 summarizes the clinical and laboratory data for T2DM patients according to the different genotypes of the rs7903146 SNP. There were no significant differences among the three rs7903146 SNP genotypes in terms of systolic and diastolic BP, BMI, total cholesterol, HDL cholesterol, LDL cholesterol, HbAlc,

Table 1. Genotype and allele frequencies of the TCF7L2 rs7903146 (C/T) polymorphism in patients with type 2 diabetes mellitus (T2DM) and non-diabetic subjects

\begin{tabular}{|c|c|c|c|c|}
\hline & $\begin{array}{c}\text { T2DM patients } \\
(\mathrm{n}=953)\end{array}$ & $\begin{array}{c}\text { Non-diabetic } \\
\text { subjects }(n=535)\end{array}$ & Unadjusted P* & Adjusted OR (95\% Cl)/P† \\
\hline \multicolumn{5}{|l|}{ Genotype } \\
\hline $\mathrm{C} / \mathrm{C}$ & $382(40.1 \%)$ & 261 (48.8\%) & 0.001 & 1 \\
\hline $\mathrm{C} / \mathrm{T}$ & $415(43.5 \%)$ & $215(40.2 \%)$ & & $1.31(1.05-1.64) / 0.017$ \\
\hline $\mathrm{T} / \mathrm{T}$ & $156(16.4 \%)$ & $59(11 \%)$ & & $1.83(1.31-2.55) / 0.001$ \\
\hline \multicolumn{5}{|l|}{ Allele } \\
\hline C & 0.62 & 0.69 & 0.0001 & \\
\hline $\mathrm{T}$ & 0.38 & 0.31 & & \\
\hline \multicolumn{5}{|c|}{ Additive model } \\
\hline $\mathrm{C} / \mathrm{C}$ & $382(71.0 \%)$ & $261(81.6)$ & 0.001 & 1 \\
\hline $\mathrm{T} / \mathrm{T}$ & $156(29.0 \%)$ & 59 (18.4) & & $1.807(1.288-2.534) / 0.01$ \\
\hline \multicolumn{5}{|c|}{ Recessive model } \\
\hline $\mathrm{C} / \mathrm{C}-\mathrm{C} / \mathrm{T}$ & $797(83.6)$ & $476(88.9)$ & 0.006 & 1 \\
\hline $\mathrm{T} / \mathrm{T}$ & $156(16.4)$ & $59(11.1)$ & & $1.576(1.146-2.175) / 0.005$ \\
\hline \multicolumn{5}{|c|}{ Dominant model } \\
\hline $\mathrm{C} / \mathrm{C}$ & $382(40.0)$ & $261(48.8)$ & 0.001 & 1 \\
\hline $\mathrm{C} / \mathrm{T}-\mathrm{T} / \mathrm{T}$ & $571(60.0)$ & $274(51.2)$ & & $1.424(1.150-1.762) / 0.001$ \\
\hline
\end{tabular}

Data are presented as number (\%) or proportion. ${ }^{*} \mathrm{P}$ values were computed by $\chi^{2}$ tests comparing T2DM patients and non-diabetic subjects. ${ }^{\dagger}$ Adjusted $\mathrm{OR}(95 \% \mathrm{Cl}) / \mathrm{P}$ values were obtained from logistic regression analyses adjusting for age and gender. Only $\mathrm{P}$ values lower than the Bonferroni threshold $(P=0.010)$ were considered statistically significant.

Table 2. Clinical and laboratory characteristics of T2DM patients, broken down by presence of different TCF7L2 rs7903146 (C/T) genotypes

\begin{tabular}{|c|c|c|c|c|c|}
\hline & \multicolumn{3}{|c|}{ TCF7L2 rs7903146 (C/T) genotypes } & \multirow{2}{*}{$F / P^{*}$} & \multirow{2}{*}{$\mathbf{P}^{\dagger}$} \\
\hline & $\mathrm{C} / \mathrm{C}(\mathrm{n}=382)$ & $C / T(n=415)$ & $T / T(n=156)$ & & \\
\hline Age (years) & $58.2 \pm 10.8$ & $59.8 \pm 10.8$ & $60.3 \pm 10.2$ & - & 0.051 \\
\hline Age at diagnosis (years) & $46.6 \pm 11.9$ & $46.8 \pm 12.0$ & $47.2 \pm 12.0$ & - & 0.881 \\
\hline Gender (\% males) & 47.6 & 48.4 & 50.2 & - & 0.857 \\
\hline $\mathrm{HbA1c}(\%)^{\mathrm{a}}$ & $7.7 \pm 1.6$ & $7.5 \pm 1.6$ & $8.3 \pm 2.7$ & $2.22 / 0.113$ & - \\
\hline $\mathrm{FPG}(\mathrm{mmol} /)^{\mathrm{a}}$ & $10.23 \pm 4.18$ & $9.69 \pm 4.19$ & $10.51 \pm 3.74$ & $2.44 / 0.088$ & - \\
\hline Systolic BP $(\mathrm{mmHg})^{b}$ & $136.74 \pm 21.66$ & $135.06 \pm 20.76$ & $137.7 \pm 22.9$ & $1.03 / 0.356$ & - \\
\hline Diastolic BP (mmHg) & $83.3 \pm 11.3$ & $82.8 \pm 13.6$ & $84.3 \pm 11.8$ & $0.715 / 0.490$ & - \\
\hline $\mathrm{BMI}\left(\mathrm{kg} / \mathrm{m}^{2}\right)^{\mathrm{a}}$ & $29.05 \pm 4.9$ & $28.58 \pm 5.6$ & $28.25 \pm 4.5$ & $0.990 / 0.372$ & - \\
\hline Total cholesterol $(\mathrm{mmol} / \mathrm{l})^{\mathrm{c}}$ & $11.35 \pm 2.66$ & $10.20 \pm 2.5$ & $11.10 \pm 2.66$ & $0.371 / 0.691$ & - \\
\hline HDL cholesterol $(\mathrm{mmol} / \mathrm{l})^{c}$ & $2.34 \pm 0.64$ & $2.48 \pm 0.77$ & $2.46 \pm 0.69$ & $1.057 / 0.349$ & - \\
\hline LDL cholesterol $(\mathrm{mmol} /)^{c}$ & $6.63 \pm 2.57$ & $6.75 \pm 2.50$ & $6.51 \pm 2.15$ & $0.347 / 0.707$ & - \\
\hline Triglycerides $(\mathrm{mmol} / \mathrm{l})^{c}$ & $8.83(2-75.5)$ & $8.38(1.94-79.9)$ & $8.33(2.33-46.7)$ & $0.643 / 0.527$ & - \\
\hline Diabetic nephropathy (\%) & 48.6 & 51.0 & 50.3 & - & 0.802 \\
\hline Diabetic retinopathy (\%) & 51.6 & 49.3 & 54.5 & - & 0.555 \\
\hline
\end{tabular}

Data are mean \pm SD, median (minimum-maximum values) or \%. BMl: body mass index; BP: blood pressure; FPG: fasting plasma glucose; HbA1c: glycated hemoglobin; T2DM: type 2 diabetes mellitus. ${ }^{*} \mathrm{~F}$ and $\mathrm{P}$ values obtained from general linear model univariate analyses, after adjustment for: ${ }^{\mathrm{a}}$ age and gender; ${ }^{\mathrm{b}}$ age, gender, use of medication for hypertension, and BMl; ${ }^{\mathrm{c}}$ age, gender and use of hypolipidemic medications. ${ }^{\dagger} \mathrm{P}$ values were obtained from $\chi^{2}$ tests or ANOVA, as appropriate. Only P values lower than the Bonferroni threshold ( $\left.P=0.0042\right)$ were considered statistically significant. 
fasting plasma glucose or triglyceride levels, and prevalence of diabetic retinopathy or diabetic nephropathy, adjusting for covariables. It is worth mentioning that none of these variables attained statistical significance irrespective of whether recessive $(\mathrm{C} / \mathrm{C}-\mathrm{C} / \mathrm{T} v \boldsymbol{s} . \mathrm{T} / \mathrm{T})$, dominant $(\mathrm{C} / \mathrm{C} v s . \mathrm{C} / \mathrm{T}-\mathrm{T} / \mathrm{T})$ or additive $(\mathrm{C} / \mathrm{C} v s$. $\mathrm{T} / \mathrm{T}$ ) models of inheritance were assumed for the $\mathrm{T}$ allele (data not shown).

\section{DISCUSSION}

TCF7L2 gene is considered one of the most important candidate genes for T2DM, playing a key role in blood-glucose homeostasis and beta-cell function (30). Following the initial report by Grant and cols. (3) showing that $T C F 7 L 2$ variants were strongly associated with T2DM risk, several other studies consistently replicated this association in different ethnicities [reviewed in (4)]. Among the TCF7L2 variants, the rs7903146 $(\mathrm{C} / \mathrm{T}) \mathrm{SNP}$ seems to have the more robust effect in Caucasian populations $(4,9)$. Here, we successfully replicated the association between the TCF7L2 rs7903146 SNP and risk for T2DM in Caucasian-Brazilian subjects from Southern of Brazil, probably under an additive inheritance model given that the risk conferred by the $\mathrm{T} / \mathrm{T}$ genotype was higher than that conferred by heterozygous genotype.

The consistency in the data showing the association between TCF7L2 gene variants and risk for T2DM reported by many studies in different populations is believed to be a reliable indicative of a universal contribution of this gene to T2DM development (31), even though some studies have reported weak or no association with the disease, mainly in Asian populations (21,32-35). Thus, to date, around 10 meta-analyses evaluated the pooled effect of TCF7L2 rs7903146 SNP in T2DM risk (5-8,31,36-40).

In 2009, Tong and cols. (5) published a large meta-analysis of 36 genetic association studies examining the association of T2DM with four TCF7L2 polymorphisms (rs7903146, rs7901695, rs12255372 and rs11196205), totalizing 39,123 controls and 35,843 cases from different ethnicities. Results from the overall meta-analysis of the rs7903146 SNP showed that heterozygous carried just over a 1.4-fold increased risk for T2DM, while $\mathrm{T} / \mathrm{T}$ homozygous carried near a 2.0 -fold increase in T2DM risk, when compared with $\mathrm{C} / \mathrm{C}$ homozygous. Moreover, the authors computed attributable risk (PAR) for the T/T-T/C genotypes of $16.9 \%$ for overall, 23.2\% for Caucasians, 14.1\% for North Europeans, $2.5 \%$ for East Asians, $17.9 \%$ for Indians, and $27.0 \%$ for Africans, suggesting that this polymorphism may contribute with approximately $1 / 5$ of all T2DM risk in the globe, except for East Asians. The other three analyzed TCF7L2 variants were also significantly associated with T2DM risk in different ethnicities, and the authors suggested that the rs7903143 and rs 12255372 can be taken as reference loci for exploring T2DM susceptibility since they were associated with the highest pooled OR (5).

In 2012, the meta-analysis of Song and cols. (40) also confirmed the association of the rs7903146 SNPs with T2DM in 66 studies $(\mathrm{OR}=1.41,95 \%$ CI 1.37 1.46 for the $\mathrm{T}$ allele). Overall, they observed significant differences in the $\mathrm{T}$ allele frequencies of this SNP across different populations: this allele was quite common (0.16-0.48\%) in all Caucasians, Africans and Hispanics except for Pima Indians, but less frequent (0.02-0.04) in all East Asian populations. Despite these differences in the frequencies of the rs7903146 SNP, they found similar association results across diverse ethnic groups. These authors also quantified the associations of the rs7903146 SNP with measures of beta-cell function among 35,052 non-diabetic subjects from 31 studies. In general, $\mathrm{T}$ allele carriers had significantly lower levels of fasting insulin and homeostasis model assessment of insulin secretion (HOMA-\%B) and higher fasting glucose and $2 \mathrm{~h}$ post-load glucose levels when compared to $\mathrm{C} / \mathrm{C}$ homozygous.

Recently, Peng and cols. (6) conducted a comprehensive and updated meta-analysis regarding the association between TCF7L2 variants and T2DM. Eight TCF7L2 polymorphisms in 155 studies with 121,174 subjects $(53,385$ cases and 67,789 controls) were addressed in their meta-analysis. Significant associations were found between T2DM risk and rs7903146, rs12255372, rs11196205, rs7901695, rs7895340 and rs4506565 SNPs under an additive inheritance model. The highest pooled ORs were found for the rs7903146, rs 12255372 and rs4506565 SNPs (OR $=1.39,95 \% \mathrm{CI}$ $1.34-1.45 ;$ OR $=1.33,95 \%$ CI $1.27-1.40$; and OR = $1.39,95 \%$ CI 1.29-1.49; respectively), all of them in strong LD with each other across various populations. Subgroups analyses showed that no significant associations were found between the analyzed SNPs and T2DM in some ethnic groups as, for example, in American Pima Indians (6), showing the necessity of evaluating TCF7L2 in different populations and ethnicities. 
Three previous Brazilian studies have evaluated the association between the TCF7L2 rs7903146 SNP and T2DM. Marquezine and cols. (41) evaluated the effect of the rs7903146 SNP on diabetes risk in 560 subjects with known coronary disease enrolled in the MASS II Trial and also in 1,449 residents from Vitoria, in Southeast Brazil. They confirmed the association between the rs7903146 SNP and T2DM risk $(\mathrm{OR}=1.57$ per $\mathrm{T}$ allele, 95\% CI 1.16-2.11), but the inclusion of this SNP in an established clinical risk prediction score did not increase model accuracy. Franco and cols. (22) assessed whether the rs7903146 SNP could predict the development of glucose intolerance in Japanese-Brazilians in a population-based 7-year prospective study. In their study population, the $\mathrm{T}$ allele frequency was only $5 \%$. No significant association was found between this SNP and glucose intolerance incidence; however, C/T genotype carriers had significantly lower insulin levels $2 \mathrm{~h}$ after a 75 -g glucose load than carriers of the $\mathrm{C} / \mathrm{C}$ genotype. Barra and cols. (23) reported that the $\mathrm{T} / \mathrm{T}$ genotype was significantly associated with T2DM risk $(\mathrm{OR}=3.92,95 \% \mathrm{CI} 1.49-10.3$ for the recessive model $)$ in a small sample from the population of Brasilia, in the Central Western region of Brazil. Although they analyzed a sample of mixed ethnicity, the frequency of the T allele in their study was similar to that presented here.

The underlying mechanisms of action of TCF7L2 variants in the etiology of T2DM is still uncertain given that all the TCF7L2 SNPs identified so far are located in the intronic regions. Interestingly, none of the variants found in TCF7L2 exons were associated with T2DM (30). Thus, it is necessary to clarify how the intronic variants affect TCF7L2 gene expression. In this context, Lyssenko and cols. (42) found that rs7903146 T allele carriers exhibited a significant elevation of TCF7L2 mRNA expression in human pancreatic islets, which was associated with impaired insulin secretion and incretin effects. Moreover, $\mathrm{T}$ allele carriers had enhanced rates of hepatic glucose production (42). Gaulton and cols. (43) reported that in human islets the chromatin state at the TCF7L2 locus is more open in chromosomes carrying the rs7903146 T allele. They also created allele-specific luciferase reporter constructs and measured enhancer activity in two beta-cell lines (MIN6 and 832/13). Interestingly, T allele constructs showed significantly greater enhancer activity than the $\mathrm{C}$ allele. The authors concluded that the $\mathrm{T}$ allele affects T2DM susceptibility by altering cis regulation and local chromatin structure in human pancreatic islets. Palmer and cols. (44), through evaluation of tagging SNPs, showed that T2DM risk was limited to a $4.3-\mathrm{kb}$ region in the TCF7L2 gene, where is located the rs7903146 SNP. After sequencing this region in DNA from 96 African Americans, they reported that results of imputation, haplotype, and conditional analyses of the SNPs in this region were consistent with the rs7903146 SNP being the trait-defining variant. Thus, to date, both genetic and functional studies make a reliable case for a functional role for the rs7903146 SNP.

Some factors could have interfered with the findings of the present study. First, we cannot rule out the possibility of population stratification bias when analyzing our samples, even though only white subjects were studied and both T2DM patients and non-diabetic subjects were recruited from the same hospital, thus reducing the risk of false-positive/negative associations due to this bias. Second, we did not perform a replication of the observed association in another sample from Southern Brazil, although our data is in agreement with the majority of studies performed in different populations $(5-8,31,36-40)$ and also with another Brazilian study (23). Third, we only analyzed one SNP in the TCF7L2 gene. Therefore, even though the TCF7L2 rs7903146 SNP seems to be one of the trait-defining variants (44), we can not exclude the possibility that another polymorphism in this gene could contribute to the T2DM pathogenesis in our population. Fourth, the presence of diabetes in the non-diabetic sample was only evaluated by questionnaire. Thus, a few number of undiagnosed T2DM subjects could be present in the non-diabetic sample. However, this is a conservative bias, which only could contribute to decrease the observed OR and not to give a false-positive association.

In conclusion, in Southern Brazil, the TCF7L2 rs7903146 SNP is also associated with T2DM susceptibility. The risk conferred by the $\mathrm{T} / \mathrm{T}$ genotype was higher than that of the heterozygous genotype, which is an indicative of an additive model of inheritance, and it is in agreement with the literature reported so far.

Funding: this study was partially supported by grants from Fundação de Amparo à Pesquisa do Estado do Rio Grande do Sul (Fapergs), the Conselho Nacional de Desenvolvimento Científico e Tecnológico $(\mathrm{CNPq})$, Fundo de Incentivo à Pesquisa e Eventos (Fipe) at the Hospital de Clínicas de Porto Alegre, and Coordenação de Aperfeiçoamento de Pessoal de Nível Superior (Capes). Daisy Crispim and Luís H. Canani are recipients of scholarships from CNPq. The funders had no role in study design, data collection and analysis, decision to publish, or preparation of the manuscript. 
Disclosure: no potential conflict of interest relevant to this article was reported.

\section{REFERENCES}

1. Stumvoll M, Goldstein B, van Haeften T. Type 2 diabetes: principles of pathogenesis and therapy. Lancet. 2005;365(9467):133346.

2. Vimaleswaran KS, Loos RJ. Progress in the genetics of common obesity and type 2 diabetes. Expert Rev Mol Med. 2010;12:e7.

3. Grant SF, Thorleifsson G, Reynisdottir I, Benediktsson R, Manolescu A, Sainz J, et al. Variant of transcription factor 7-like 2 (TCF7L2) gene confers risk of type 2 diabetes. Nat Genet. 2006;38(3):320-3.

4. Florez JC. The new type 2 diabetes gene TCF7L2. Curr Opin Clin Nutr Metab Care. 2007;10(4):391-6.

5. Tong Y, LinY, Zhang Y, Yang J, Liu H, Zhang B. Association between TCF7L2 gene polymorphisms and susceptibility to type 2 diabetes mellitus: a large Human Genome Epidemiology (HuGE) review and meta-analysis. BMC Med Genet. 2009;10:15.

6. Peng S, ZhuY, Lü B, Xu F, Li X, Lai M.TCF7L2 gene polymorphisms and type 2 diabetes risk: a comprehensive and updated metaanalysis involving 121,174 subjects. Mutagenesis. 2013;28(1):2537.

7. Dou H, Ma E, Yin L, Jin Y, Wang H. The association between gene polymorphism of TCF7L2 and type 2 diabetes in Chinese Han population: a meta-analysis. PLoS One. 2013;8(3):e59495.

8. Wang J, Hu F, Feng T, Zhao J, Yin L, Li L, et al. Meta-analysis of associations between TCF7L2 polymorphisms and risk of type 2 diabetes mellitus in the Chinese population. BMC Med Genet. 2013;14:8.

9. Ip W, Chiang YT, Jin T. The involvement of the wnt signaling pathway and TCF7L2 in diabetes mellitus: The current understanding, dispute, and perspective. Cell Biosci. 2012;2(1):28.

10. Prestwich TC, Macdougald OA. Wnt/beta-catenin signaling in adipogenesis and metabolism. Curr Opin Cell Biol. 2007;19(6):612-7.

11. da Silva Xavier G, Loder MK, McDonald A, Tarasov Al, Carzaniga R, Kronenberger $\mathrm{K}$, et al. TCF7L2 regulates late events in insulin secretion from pancreatic islet beta-cells. Diabetes. 2009;58(4):894-905.

12. Loder MK, da Silva Xavier G, McDonald A, Rutter GA. TCF7L2 controls insulin gene expression and insulin secretion in mature pancreatic beta-cells. Biochem Soc Trans. 2008;36(Pt 3):357-9.

13. Yi F, Brubaker PL, Jin T. TCF-4 mediates cell type-specific regulation of proglucagon gene expression by beta-catenin and glycogen synthase kinase-3beta. J Biol Chem. 2005;280(2):1457-64.

14. Smith U.TCF7L2 and type 2 diabetes--we WNT to know. Diabetologia. 2007;50(1):5-7.

15. Weedon MN. The importance of TCF7L2. Diabetic Medicine. 2007;24(10):1062-6.

16. Schäfer SA, Machicao F, Fritsche A, Häring HU, Kantartzis K. New type 2 diabetes risk genes provide new insights in insulin secretion mechanisms. Diabetes Res Clin Pract. 2011;93 Suppl 1:S9-24.

17. Ezzidi I, Mtiraoui N, Cauchi S, Vaillant E, Dechaume A, Chaieb M, et al. Contribution of type 2 diabetes associated loci in the Arabic population from Tunisia: a case-control study. BMC Med Genet. 2009;10:33.

18. Gonzalez-Sanchez JL, Martinez-Larrad MT, Zabena C, PerezBarba M, Serrano-Rios M. Association of variants of the TCF7L2 gene with increases in the risk of type 2 diabetes and the proinsulin:insulin ratio in the Spanish population. Diabetologia. 2008;51(11):1993-7.

19. Cauchi S, Meyre D, Dina C, Choquet H, Samson C, Gallina S, et al. Transcription factor TCF7L2 genetic study in the French population: expression in human beta-cells and adipose tissue and strong association with type 2 diabetes. Diabetes. 2006;55(10):2903-8.

20. Wen J, Ronn T, Olsson A, Yang Z, Lu B, Du Y, et al. Investigation of type 2 diabetes risk alleles support CDKN2A/B, CDKAL1, and TCF7L2 as susceptibility genes in a Han Chinese cohort. PLoS One. 2010;5(2):e9153.

21. Chang YC, Chang TJ, Jiang YD, Kuo SS, Lee KC, Chiu KC, et al. Association study of the genetic polymorphisms of the transcription factor 7-like 2 (TCF7L2) gene and type 2 diabetes in the Chinese population. Diabetes. 2007;56(10):2631-7.

22. Franco LF, Crispim F, Pereira AC, Moises RS. Variants of transcription factor 7-like 2 (TCF7L2) gene and incident glucose intolerance in Japanese-Brazilians. Braz J Med Biol Res. 2011;44(3):240-4.

23. Barra GB, Dutra LA, Watanabe SC, Costa PG, Cruz PS, Azevedo $M F$, et al. Association of the rs7903146 single nucleotide polymorphism at theTranscription Factor 7-like 2 (TCF7L2) locus with type 2 diabetes in Brazilian subjects. Arq Bras Endocrinol Metabol. 2012;56(8):479-84

24. Canani L, Capp C, Ng D, Choo S, Maia A, Nabinger G, et al. The fatty acid-binding protein-2 A54T polymorphism is associated with renal disease in patients with type 2 diabetes. Diabetes. 2005;54(11):3326-30.

25. American Diabetes Association. Diagnosis and Classification of Diabetes Mellitus. Diabetes Care. 2013; 35(Suppl. 1):S64-S71.

26. Bouças AP, Brondani LA, Souza BM, Lemos NE, de Oliveira FS, Canani LH, et al. The A allele of the rs1990760 polymorphism in the IFIH1 gene is associated with protection for arterial hypertension in type 1 diabetic patients and with expression of this gene in human mononuclear cells. PLoS One. 2013;8(12):e83451.

27. Camargo JL, Zelmanovitz T, Paggi A, Friedman R, Gross JL. Accuracy of conversion formulae for estimation of glycohaemoglobin. Scand J Clin Lab Invest. 1998;58(6):521-8.

28. Lahiri DN, Urnberger J. A rapid non-enzymatic method for the preparation of HMW DNA from blood for RFLP studies. Nucleic Acids Res. 1991;19(19):5444.

29. de Souza BM, Assmann TS, Kliemann LM, Marcon AS, Gross JL, Canani $\mathrm{LH}$, et al. The presence of the $-866 \mathrm{~A} / 55 \mathrm{Val} / \mathrm{lns}$ haplotype in the uncoupling protein 2 (UCP2) gene is associated with decreased UCP2 gene expression in human retina. Exp Eye Res. 2012;94(1):49-55.

30. Uma Jyothi K, Jayaraj M, Subburaj KS, Prasad KJ, Kumuda I, Lakshmi V, et al. Association of TCF7L2 gene polymorphisms with T2DM in the population of Hyderabad, India. PLoS One. 2013;8(4):e60212.

31. Cauchi S, El AchhabY, Choquet H, Dina C, Krempler F, Weitgasser $R$, et al.TCF7L2 is reproducibly associated with type 2 diabetes in various ethnic groups: a global meta-analysis. J Mol Med (Berl). 2007;85(7):777-82.

32. GuoT, Hanson RL, Traurig M, MullerYL, Ma L, Mack J, et al.TCF7L2 is not a major susceptibility gene for type 2 diabetes in Pima Indians: analysis of 3,501 individuals. Diabetes. 2007;56(12):3082-8.

33. Kifagi C, Makni K, Boudawara M, Mnif F, Hamza N, Abid M, et al. Association of genetic variations in TCF7L2, SLC30A8, HHEX, LOC387761, and EXT2 with Type 2 diabetes mellitus in Tunisia. Genet Test Mol Biomarkers. 2011;15(6):399-405.

34. Park SE, LeeWY, Oh KW, Baek KH,Yoon KH, Kang MI, et al. Impact of common type 2 diabetes risk gene variants on future type 2 diabetes in the non-diabetic population in Korea. J Hum Genet. 2012;57(4):265-8.

35. Zheng X, Ren W, Zhang S, Liu J, Li S, Li J, et al. Association of type 2 diabetes susceptibility genes (TCF7L2, SLC30A8, PCSK1 and PCSK2) and proinsulin conversion in a Chinese population. Mol Biol Rep. 2012;39(1):17-23. 
36. LuoY, Wang H, Han X, Ren Q, Wang F, Zhang X, et al. Meta-analysis of the association between SNPs in TCF7L2 and type 2 diabetes in East Asian population. Diabetes Res Clin Pract. 2009;85(2):139-46.

37. Takeuchi $\mathrm{M}$, Okamoto $\mathrm{K}$, Takagi $\mathrm{T}$, Ishii $\mathrm{H}$. Ethnic difference in patients with type 2 diabetes mellitus in inter-East Asian populations: a systematic review and meta-analysis focusing on gene polymorphism. J Diabetes. 2009;1(4):255-62.

38. Berhouma R, Kouidhi S, Ammar M, Abid H, Baroudi T, Ennafaa $\mathrm{H}$, et al. Genetic susceptibility to type 2 diabetes: a global metaanalysis studying the genetic differences in Tunisian populations. Hum Biol. 2012;84(4):423-35.

39. Wang J, Li L, Zhang J, Xie J, Luo X, Yu D, et al. Association of rs7903146 (IVS3C/T) and rs290487 (IVS3C/T) polymorphisms in TCF7L2 with type 2 diabetes in 9,619 Han Chinese population. PLoS One. 2013;8(3):e59053.

40. Song Y, Yeung E, Liu A, Vanderweele TJ, Chen L, Lu C, et al. Pancreatic beta-cell function and type 2 diabetes risk: quantify the causal effect using a Mendelian randomization approach based on meta-analyses. Hum Mol Genet. 2012;21(22):5010-8.

41. Marquezine GF, Pereira AC, Sousa AG, Mill JG, Hueb WA, Krieger JE. TCF7L2 variant genotypes and type 2 diabetes risk in Brazil: significant association, but not a significant tool for risk stratification in the general population. BMC Med Genet. 2008;9:106.

42. Lyssenko V, Lupi R, Marchetti $P$, Del Guerra S, Orho-Melander $\mathrm{M}$, Almgren $\mathrm{P}$, et al. Mechanisms by which common variants in the TCF7L2 gene increase risk of type 2 diabetes. J Clin Invest. 2007;117(8):2155-63.

43. Gaulton KJ, Nammo T, Pasquali L, Simon JM, Giresi PG, Fogarty MP, et al. A map of open chromatin in human pancreatic islets. Nat Genet. 2010;42(3):255-9.

44. Palmer ND, Hester JM, An SS, Adeyemo A, Rotimi C, Langefeld $C D$, et al. Resequencing and analysis of variation in the TCF7L2 gene in African Americans suggests that SNP rs7903146 is the causal diabetes susceptibility variant. Diabetes. 2011;60(2):662-8. 